\title{
STUDI KELAYAKAN PEMBANGUNAN APARTEMEN DI JL. JATIBENING RAYA, PONDOKGEDE, KOTA BEKASI
}

\author{
Jeremia Josiah ${ }^{1)}$, Priyendiswara $\mathrm{AB}^{2)}$, B Irwan Wipranata ${ }^{3)}$, Bambang Deliyanto ${ }^{4)}$
}

\footnotetext{
1)Program Studi S1 PWK, Fakultas Teknik, Universitas Tarumanagara, jeremiaajosiah@gmail.com 2)Program Studi S1 PWK, Fakultas Teknik, Universitas Tarumanagara, priyendiswaraa@ft.untar.ac.id 3)Program Studi S1 PWK, Fakultas Teknik, Universitas Tarumanagara, irwan_wipranata@yahoo.co.uk

4)Program Studi S1 PWK, Fakultas Teknik, Universitas Tarumanagara, deli.bambang@gmail.com
}

\begin{abstract}
Abstrak
Pertumbuhan pengembangan properti yang terus meningkat di Indonesia, terutama pada kota Jakarta menyebabkan terjadinya keterbatasan lahan dan naiknya nilai lahan sehingga membuat tren pengembangan properti khususnya kawasan hunian seperti apartemen mulai bergeser ke daerah kota - kota penyangga. Pengembangan kawasan hunian juga didorong oleh peningkatan penduduk yang cukup tinggi di Indonesia sehingga kebutuhan akan hunian juga semakin meningkat. Kota Bekasi merupakan salah satu kota penyangga dari kota Jakarta yang sudah memiliki infrastruktur cukup baik terutama di sektor transportasi dan saat ini sedang dilakukan pembangunan jalur LRT Cawang-Bekasi Timur yang akan semakin meningkatkan kemudahan aksesibilitas transportasi dari/menuju kota Bekasi. Dengan melihat peluang yang ada, maka direncanakan pembangunan apartemen pada objek lahan kosong yang terletak di Jl. Jatibening Raya, Kel. Jatibening Baru, Kec. Pondogede, Kota Bekasi. Lokasi lahan yang berada dalam radius rencana dari 2 stasiun LRT dan tren pembangunan apartemen yang terjadi selama 5 tahun terakhir di sekitar lahan pengembangan juga memberikan peluang untuk pembangunan apartemen pada objek studi yang ditargetkan untuk para commuter, termasuk para generasi milenial. Tujuan studi kelaykan ini adalah untuk mengetahui kelayakan pembangunan apartemen yang didasarkan pada luas lahan yang relatif kecil, agar dapat mengetahui potensi dan kelemahan yang ada. Kelayakan dilihat melalui analisis pada aspek legalitas, teknis dan investasi yang dilakukan menggunakan metode kualitatif. Hasil studi kelayakan ini adalah memberikan rekomendasi kelayakan pembangunan dari alternatif komposisi produk yang dapat memberikan pengembalian investasi terbaik.
\end{abstract}

Kata kunci: apartemen; investasi; pembangunan; studi kelayakan

\begin{abstract}
Property development growth are still continue to increase in Indonesia, especially in the city of Jakarta which causes land limitations and land values to increase that make property development trend especially residential areas such as apartment has begun shift to buffer city area. Development of residential area is also supported by growth population in Indonesia that increased quite high so the need for residence also increase. Bekasi is one of the buffer city of Jakarta which already has good infrastructure especially in the transportation sector and currently under construction for Cawang-East Bekasi LRT line which will further improve the accessibility of transportation to/form of city of Bekasi. By looking at that opportunities, an apartment development is planned on the vacant land located at Jl. Jatibening Raya, Jatibening Baru, Pondokgede, city of Bekasi. The location of the land is within the planned radius of the 2 LRT stations and the trend of apartment development that has occurred over the last 5 years around the location of the land also provides opportunities for apartment development in the land of object study which is targeted at commuters, also millennials generation. The purpose of this feasibility study is to determine the feasibility of an apartemen development based on a relatively small area of land object study to know the potential and weaknesses. Feasibility of development is seen through analysis on legality, technical and investment aspects that carried out using qualitative methods. The results of this feasibility study are to provide recommendation of
\end{abstract}


feasibility development from alternative product compositions that can provide the best return on investment.

Keywords: apartment; development; feasibility study; investment

\section{PENDAHULUAN Latar Belakang}

Tren pertumbuhan pengembangan properti yang terus meningkat di Indonesia yaitu berada angka 5,49\% pada tahun 2019 dan diprediksi akan terus meningkat. Pembangunan properti yang terjadi terutama pada kawasan ibu kota seperti Jakarta yang menyebabkan terjadinya keterbatasan lahan dan naiknya nilai lahan sehingga membuat tren pengembangan properti khususnya kawasan hunian seperti apartemen mulai bergeser ke daerah kota - kota penyangga. Pertumbuhan kawasan hunian ini juga didorong oleh pertumbuhan penduduk yang terus meningkat di Indonesia setiap tahunnya yaitu sebesar $1,2 \%$. Kota Penyangga yang dipilih sebagai lokasi pengembangan kawasan hunian adalah yang memiliki perkembangan kawasan dan infrastruktur yang memadai. Salah satu infrastruktur yang cukup penting adalah transportasi, karena mayoritas masyarakat akan beraktivitas di kota Jakarta. Kota Bekasi merupakan salah satu kota penyangga Jakarta yang memiliki perkembangan cukup pesat dan memiliki infrastruktur transportasi cukup baik seperti adanya jalan tol Jakarta-Cikampek, jalan tol Becakayu dan jalur Kereta Rel Listrik (KRL). Saat ini juga sedang dilakukan pembangunan jalur kereta LRT Cawang - Bekasi Timur yang akan menambah kemudahan aksesibilitas dari kota Bekasi. Meskipun merupakan kota penyangga dari Jakarta, dikarenakan pengembangan yang sudah banyak terjadi, ketersediaan lahan kosong di kota Bekasi saat ini tidak seperti pada saat awal pengembangannya yang banyak dibangun kawasan landed house. Sehingga saat ini tren pengembangan kawasan hunian di kota Bekasi pun sudah mengikuti kota Jakarta dan kota besar lainnya yaitu dengan pembangunan kawasan apartemen.

Dengan melihat potensi yang ada, maka direncanakan pembangunan apartemen di lahan kosong yang berlokasi di Jl. Jatibening Raya, Kec. Jatibening Baru, Pondokgede, Kota Bekasi. Lokasi lahan sendiri berada di dalam 2 radius stasiun LRT yang memiliki jarak terhadap lahan $1,5 \mathrm{~km}$ dan $3 \mathrm{~km}$. Tren pengembangan apartemen di kota Bekasi juga sudah terjadi pada kawasan Jatibening, dimana saat ini terdapat 4 apartemen yang terdiri dari 1 apartemen eksisting dan 3 apartemen yang sedang dibangun (future supply). Luas lahan pengembangan sendiri tergolong cukup kecil yaitu $8.500 \mathrm{~m}^{2}$, sehingga diperlukan untuk dilakukan studi kelayakan dalam pembangunan apartemen ini terutama dari aspek legalitas, dimana lokasi lahan juga berdekatan dengan bandara Halim Perdana Kusuma karena dalam pembangunan apartemen ketinggian bangunan adalah hal yang cukup penting karena menentukan jumlah lantai yang akan direncanakan. Aspek lain yang perlu dilihat adalah teknis, pasar dan investasi dengan menentukan komposisi produk yang dapat dikembangkan.

\section{Rumusan Permasalahan}

a. Bagaimanakah kondisi dan peluang dari pasar apartemen disekitar lokasi lahan?

b. Berapakah besar pengembalian investasi pada lahan kosong di Jl. Jatibening Raya, Kota Bekasi yang paling menguntungkan?

\section{Tujuan}

Mengidentifikasi potensi dan masalah dari lahan yang dikembangkan yang ada baik dari faktor internal maupun eksternal, serta melihat kondisi dan peluang yang ada dari pasar dan kompetitor sejenis di kawasan sekitar. Sehingga dapat memberikan rekomendasi kelayakan investasi pembangunan dengan perencanaan alternatif komposisi produk yang dapat dikembangkan yang memberikan pengembalian investasi yang terbaik. 


\section{KAJIAN LITERATUR}

Properti adalah semua bangunan yang ada di atas permukaan bumi yang menjulang ke angkasa yang melekat secara permanen baik secara alamiah maupun campur tangan manusia (Braid \& Kyle, 1991). Apartemen adalah suatu ruang atau rangkaian ruang yang dilengkapi dengan fasilitas yang digunakan bersama serta perlengkapan rumah tangga dan digunakan sebagai tempat tinggal (Harris, 1975).

Investasi didefinisikan sebagai penempatan sejumlah dana pada saat ini dengan harapan untuk memperoleh keuntungan di masa mendatang (Halim, 2003). Investasi dapat dibedakan menjadi 2 (dua) yaitu :

a. Investasi pada financial assets, yaitu investasi yang dilakukan di pasar uang dan pasar modal, seperti deposito, commercial paper, saham, obligasi.

b. Investasi pada real assets, yaitu investasi yang diwujudkan dalam bentuk pembelian asset produktif, pendirian pabrik, pembukaan pertambangan, pembukaan perkebunan dan lainnya.

Investasi properti dapat berbentuk tanah ataupun rumah yang dilakukan untuk menghasilkan sewa atau untuk mendapatkan kenaikan nilai/harga atau keduanya. Investasi properti dapat menghasilkan kas secara mandiri tanpa tergantung dengan aset lain yang dimiliki oleh investor (Hamidah, 2016). Terdapat 2 (dua) keuntngan yang akan didapat dari investasi properti, yaitu:

a. Menyewakan properti tersebut ke pihak lain sehingga mendapatkan uang sewa,

b. Menjual properti tersebut dengan harga yang lebih tinggi.

Feasibility study adalah sebuah studi yang bertujuan menentukan apakah suatu usulan pengembangan di suatu lahan dapat berhasil dijalankan. Bedasarkan hasil dari analisis, studi kelayakan dapat dilakukan untuk memberikan kelayakan properti yang akan dikembangkan dengan membeikan penilaian yang realistis dari seluruh biaya dan manfaat yang termasuk kedalam proposal proyek dan menetapkan keuntungan bersama bersamaan dengan merencanakan investasi modal yang dibutuhkan dan penilaian risiko yang akan dihadapi. (Huxham, 2010). Hasil dari feasibility study yang adalah alternatif untuk pengembangan properti, setiap alternatif tersebut memiliki kombinasi kelayakan masing - masing yang nantinya dapat dibandingkan. Dengan melakukan perbandingan maka akan didapatkan alternatif yang optimal yang telah disempurnakan dari alternatif awal tersebut. Output/hasil dari fase ini harus mencakup setidaknya memiliki 2 komponen, yaitu : suatu keputusan untuk dikempangkan atau tidak, jika keputusan akan dilakukan pembangunan, maka harus dijelaskan mengenai apa yang akan dikembangkan, bagaimana akan dikembangkan dan kapan dimulainya pengembangan tersebut. (Huxham, 2010).

\section{METODE}

Metode dalam studi kelayakan ini menggunakan pendekatan kuantitatif untuk perhitungan analisis investasi, serta pendekatan kualitatif untuk analisis lokasi dan tapak, analisis pasar dan analisis kebutuhan ruang. Penulis merumuskan masalah bedasarkan survey melalui media penghubung dan mendapatkan data - data sekunder. Setelah menemukan potensi ataupun masalah maka penulis juga melakukan survey langsung ke lahan kosong yang menjadi objek studi, yaitu tepatnya berada di Jl. Jatibening Raya, Kelurahan Jatibening Baru, Kecamatan Pondokgede, Kota Bekasi untuk memastikan potensi dan masalah yang ditemukan. Pada studi ini digunakan data primer yang diperoleh secara langsung dengan menggunakan pendekatan wawancara, seperti data yang bersumber dari pemilik lahan, penjaga lahan dan masyarakat sekitar, termasuk narasumber dari kompetitor sejenis yang dibutuhkan dalam mengetahui kondisi pasar yang ada. Sedangkan data sekunder diperoleh secara tidak langsung melalui media penghubung, yang dalam hal ini adalah media elektronik. Beberapa contoh data sekunder 
diantaranya adalah data dari makro ekonomi, pertumbuhan jumlah penduduk dan rencana kota serta kawasan. Dalam melakukan survey lapangan penulis juga melakukan dokumentasi yang digunakan sebagai data pendukung. Analisis yang dilakukan dalam studi ini adalah analisis legalitas, analisis lokasi dan tapak, analisis pasar baik secara makro dan mikro, analisis kebutuhan ruang dan komposisi produk serta analisis investasi.

Salah satu metode pendekatan yang dapat digunakan dalam melakukan studi kelayakan (feasibility study) pada tahap analisis investasi adalah metode Discounted Cash Flow (DCF). Discounted Cash Flow dilakukan untuk menghitung prospek pertumbuhan suatu instrument investasi dalam beberapa waktu ke depan. Discounted Cash Flow terdiri dari beberapa indikator dasar yaitu :

\section{a. Cashflow}

Adalah arus kas masuk dan arus keluar kas atau setara kas (Ikatan Akuntan Indonesia, 2005). Cashflow dapat digunakan untuk melihat besar pendapatan yang akan diterima dibandingkan dengan nilai investasi saat ini dengan memperhatikan nilai investasi, operating cashflow dan terminal value.

b. Net Present Value (NPV)

Net Present Value (NPV) adalah kelebihan Present Value dari cashflow yang dihasilkan suatu proyek atas sejumlah investasi awal. NPV digunakan untuk menghitung selisih antara nilai sekarang dengan nilai penerimaan kas bersih di masa mendatang. Selain itu NPV juga berfungsi untuk mengetahui kelayakan suatu dari proyek, jika NPV bernilai positif maka proyek akan diterima, sedangkan jika NPV bernilai negatif maka proyek akan ditolak.

NPV memiliki Rumus :

$$
N P V=\sum_{t-1}^{T} \frac{C_{t}}{(1+r)^{t}}-C_{0}
$$

Keterangan:

NPV $=$ Net Present Value

$\mathrm{Ct}=$ Arus Kas per tahun pada periode $\mathrm{t}$

Co $=$ Nilai investasi awal pada tahun ke 0

$r=$ suku bunga atau discount rate (\%)

c. Internal Rate of Return (IRR)

Internal Rate of Return adalah sebuah metode untuk menghitung tingkat suku bunga (discount rate), yang membuat nilai sekarang dari seluruh perkiraan dalam pendapatan dari suatu investasi (cashinflow) sama dengan nilai sekarang (Present Value) (Hazen, 2003). Internal Rate of Return (IRR) memiliki peran yang sama dengan NPV yaitu untuk mengetahui kelayakan investasi dari suatu proyek. IRR merupakan tingkat bunga yang dapat membuat nilai NPV yang dihitung menjadi sama dengan nol $(N P V=0)$. IRR memilki rumus:

Keterangan :

$$
\mathrm{IRR}=\mathrm{r} 1+(\mathrm{r} 2-\mathrm{r} 1) \mathrm{x} \frac{\mathrm{NPV} 1}{\mathrm{NPV} 1+|\mathrm{NPV} 2|}
$$

IRR = Internal Rate Of Return

$\mathrm{r} 1$ = tingkat bunga kecil (menghasikan NPV +)

r2 = tingkat bunga besar (menghasilkan NPV -)

NPV1 $=$ NPV bernilai positif

NPV2 $=$ NPV bernilai negatif

d. Profitability Index (PI)

Profitability Index adalah adalah rasio Present Value (PV) dari cashflow setelah investasi 
awal pada tahun ke-0 dengan jumlah investasi awal tahun ke-0 atau cashflow dimasa mendatang dibagi denganinvestasi. PI akan diterima bila nilai PI>1 sedangkan bila PI bernilai $<1$ maka proyek tersebut akan ditolak. PI memiliki rumus:

$$
P I=\frac{\text { Nilai aliran kas masuk }}{\text { Nilai investasi }}
$$

e. Payback Period

Payback Period adalah jangka waktu kembalinya investasi yang telah dikeluargan melalui keuntungan yang didapatkan dari suatu proyek yang sudah dibuat. Payback Period memiliki rumus:

$$
\text { Payback Period }=n+\frac{(a-b)}{(c-b)} \times 1 \text { tahun }
$$

\section{Keterangan :}

$\mathrm{n}=$ Tahun terakhir dimana jumlah arus kas masih belum bisa menutup investasi awal

a = Jumlah investasi awal

$\mathrm{b}=$ Jumlah kumulatif arus kas pada tahun ke $-\mathrm{n}$

$\mathrm{c}=$ Jumlah kumulatif arus kas pada tahun ke $\mathrm{n}+1$

\section{DISKUSI DAN HASIL}

Lokasi lahan pengembangan berada di Jl. Jatibening Raya, Kelurahan Jatibening Baru, Kecamatan Pondokgede, Kota Bekasi. Berikut ini adalah profil dari lahan pengembangan:

Tabel 1. Profil Lahan Pengembangan

\begin{tabular}{ll}
\hline Lokasi & $\begin{array}{l}\text { Jl. Jatibening Raya, Kelurahan Jatibening Baru, Kecamatan } \\
\text { Pondokgede, Kota Bekasi }\end{array}$ \\
\hline Luas & $8.500 \mathrm{~m}^{2}$ \\
\hline Bentuk & Tidak beraturan \\
\hline Kondisi & Lahan kosong yang siap dikembangkan \\
\hline Surat Kepemilikan & Sertifikat Hak Milik \\
\hline Peruntukan & Kawasan hunian kepadatan tinggi \\
\hline
\end{tabular}

Sumber: Olahan Penulis, 2019

Lokasi lahan pengembangan berada di Jl. Jatibening Raya yang merupakan jalan kolektor sekunder, dengan luas $8.500 \mathrm{~m}^{2}$ dan memiliki bentuk tidak beraturan, lahan memiliki lebar muka $10 \mathrm{~m}$ dengan jarak dari Jl. Jatibening Raya adalah sekitar $80 \mathrm{~m}$. Kondisi lahan pengembangan ketika cukup baik dan terolong lahan yang siap untuk dikembangkan karena mayoritas bagian dari lahan merupakan tanah yang datar, hanya terdapat rumput - rumput yang perlu dibersihkan. Bedasarkan peruntukan menurut RTRW Kota Bekasi tahun 2011 - 2031 lahan pengembangan memilki peruntukan sebagai kawasan Hunian Kepadatan Tinggi yang cukup sesuai jika ingin dikembangkan sebagai kawasan apartmen. Kawasan disekitar lahan pun peruntukannya cukup beragam, dimana terdapat kawasan perumukiman landed house dan apartemen, kawasan komersial dan kawasan campuran serta beberapa fasilitas seperti sekolah, puskesmas atau masjid. 


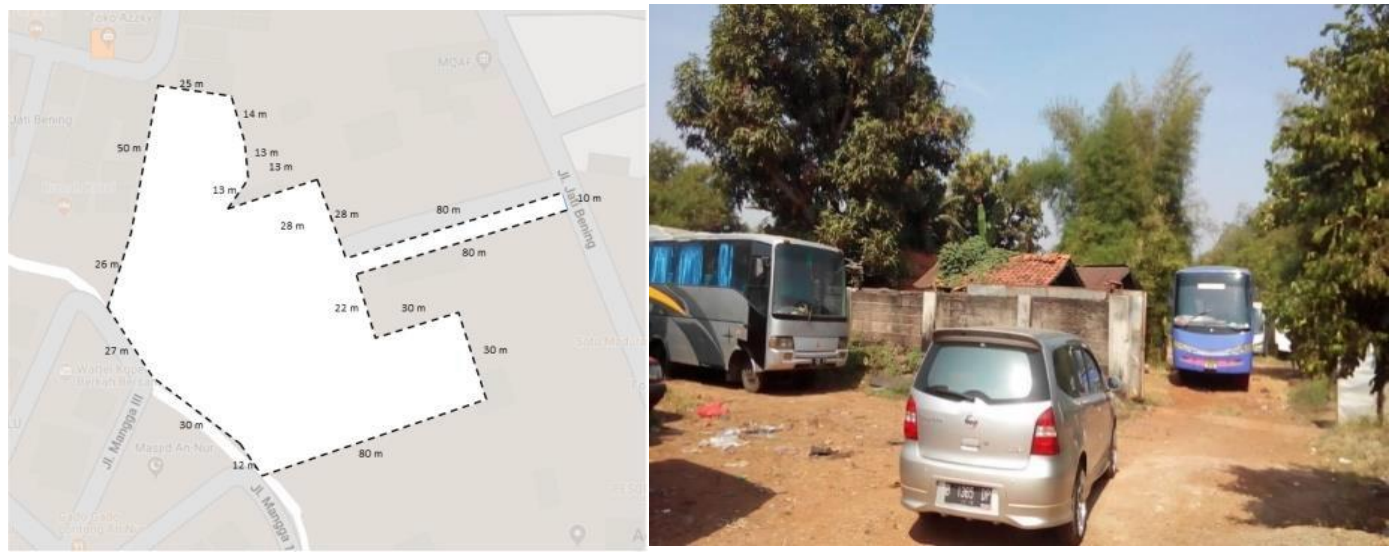

Gambar 1. Bentuk Lahan dan Kondisi di Dalam Lahan

Sumber : Dokumentasi Penulis dan Google Mymaps, 2019

Aspek legalitas dari lahan pengembangan selain merupakan kawasan Hunian Kepadatan Tinggi, terdapat beberapa ketentuan lainnya seperti syarat teknis yang terdiri dari KDB, KLB, KB dan KDH. Ketentuan syarat teknis ini didasarkan kepada peraturan Revisi RTRW Kota Bekasi 2011 2031 untuk mengembangkan kawasan apartemen di kota Bekasi, Peraturan mengacu kepada UU No. 1 Tahun 2011 tentang Perumahan dan Permukiman yang bedasarkan pada Permen Pu No. 17/PRT/M/2009 tentang Pedoman Penyusunan RTRW Kota. Berikut ini adalah syarat teknis dari lahan pengembangan:

Tabel 2. Perhitungan Syarat Teknis Lahan Pengembangan

\begin{tabular}{|c|c|c|c|}
\hline Syarat & Kondisi Eksisting Lahan & Keterangan & Ketentuan yang diperoleh \\
\hline Luas $\min 5.000 \mathrm{~m}^{2}$ & Luas $8.500 \mathrm{~m}^{2}$ & Terpenuhi & 1. KDB : Max. 50\% \\
\hline $\begin{array}{l}\text { Berada pada Kawasan } \\
\text { Penduduk kepadatan } \\
\text { tinggi }\end{array}$ & $\begin{array}{l}\text { Kawasan } \\
\text { Penduduk } \\
\text { kepadatan tinggi }\end{array}$ & Terpenuhi & $\begin{array}{l}\text { 2. KLB Max. } 11,2 \\
\text { 3. KB : Sesuai dengan } \\
\text { ketentuan KKOP Bandara }\end{array}$ \\
\hline $\begin{array}{l}\text { Berada pada minimal } \\
\text { jalan kolektor }\end{array}$ & $\begin{array}{l}\text { Jl. Jatibening Raya } \\
\text { (Jalan kolektor } \\
\text { sekunder) }\end{array}$ & Terpenuhi & $\begin{array}{l}\text { Halim Perdana Kusuma } \\
\text { 4. Jumlah lantai : } 20-30 \\
\text { lantai }\end{array}$ \\
\hline ROW jalan $\min 12 \mathrm{~m}$ & ROW $12 \mathrm{~m}$ & Terpenuhi & 5. KDH : Min. $20 \%$ \\
\hline
\end{tabular}

Sumber: File Revisi RTRW Kota Bekasi 2011 - 2031

Dengan memenuhi persyaratan yang ditentukan maka lahan pengembagan mendapatkan KDB, KLB, jumlah lantai maskimal dan minimum KDH yang ditetapkan. Sedangkan peraturan terhadap Ketinggian Bangunan (KB) dilihat kepada KKOP Bandara Halim Perdana Kusuma dikarenakan lahan pengembangan berada di Kecamatan Pondokgede yang sebagian wilayahnya termasuk atau bersinggungan dengan kawasan KKOP Bandara Halim Perdana Kusuma. Peraturan KKOP bandara Halim Perdana Kusuma yang mengacu kepada Keputusan Menteri Perhubungan No: KM 48 Tahun 2000 bahwa kawasan di bawah permukaan horizontal landasan terbagi atas 2 (dua) yaitu Kawasan di bawah Permukaan Horizontal Dalam dan Kawasan di bawah Permukaan Horizontal Luar yang memiliki jarak radius $4.000 \mathrm{~m}$ dan $15.000 \mathrm{~m}$ dari titik tengah setiap ujung permukaan utama (landasan).

Lahan pengembangan sendiri memiliki jarak dengan bandara Halim Perdana Kusuma jika dilakukan perhitungan dari ujung titik tengah landasan pacu 24 Bandara Halim Perdana Kusuma maka lahan pengembangan berjarak sebesar 4,33 km (4,330m), bedasarkan peratuan dari KKOP Bandara Halim Perdana Kusuma maka lahan pengembangan berada pada kawasan dibawah 
Permukaan Horizontal Luar (memiliki jarak $>4.000 \mathrm{~m}$ dan $<15.000$ ) yang berarti tidak termasuk Kawasan Pendekatan dan Lepas Landas dan Kawasan di bawah permukaan Kerucut. Berikut ini adalah gambaran radius $4.000 \mathrm{~m}(4 \mathrm{~km})$ dari Bandara Halim Perdana Kusuma.

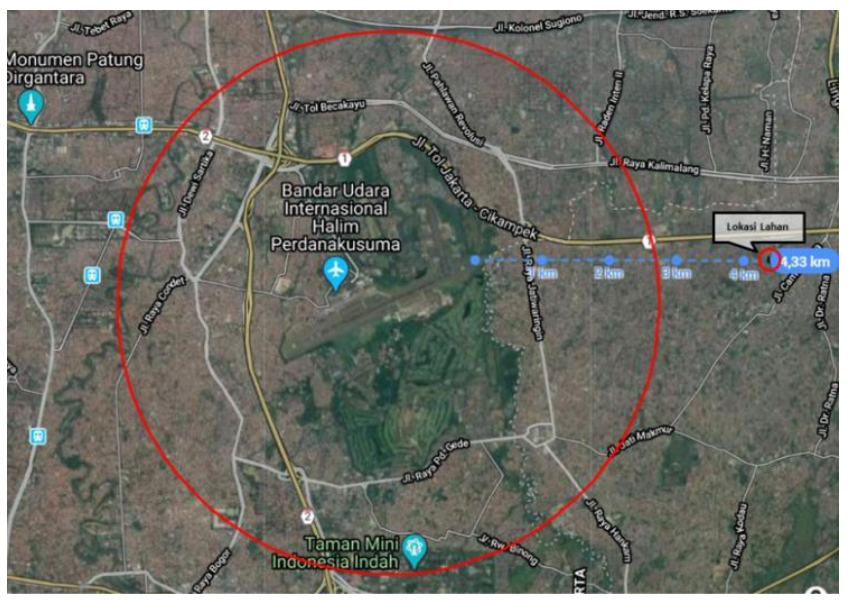

Gambar 2. Jarak Lahan Pengembangan terhadap Bandara Halim Perdana Kusuma Sumber : Olahan Penulis dan Google Mymaps, 2019

Pada Peraturan KKOP tidak dibahas mengenai ketinggian bangunan maksimal dari bangunan yang termasuk kedalam kawasan KKOP. Sehingga ketinggian bangunan didasarkan kepada Lampiran No. 5 Permen No. 20/PRT/M/2011 yang mengatur ketinggian bangunan dari wilayah yang termasuk kedalam kawasan KKOP bandara, dimana didapatkan dengan jarak $4.330 \mathrm{~m}$ maka termasuk kedalam daerah keliling 2 yang memiliki ketinggian maksimal adalah 151,5 m. Sehingga berikut ini adalah perhitungan dari syarat teknis yang dimiliki oleh lahan pengembangan:

Tabel 3. Syarat Teknis Legalitas Lahan Pengembangan

\begin{tabular}{|c|c|c|c|}
\hline $\begin{array}{l}\text { Ketentuan } \\
\text { Teknis }\end{array}$ & Besaran & $\begin{array}{c}\text { Rencana } \\
\text { Pengembangan }\end{array}$ & Perhitungan \\
\hline KDB & Max. 50\% & $40 \%$ & $\begin{array}{c}\text { Luas lahan } \times \text { KDB }= \\
8.500 \mathrm{~m}^{2} \times 40 \%=3.400 \mathrm{~m}^{2}\end{array}$ \\
\hline KLB & Max. 11,2 & 11,2 & $\begin{array}{c}\text { Luas lahan } \times \text { KLB }= \\
8.500 \mathrm{~m}^{2} \times 11,2=95.200 \mathrm{~m}^{2}\end{array}$ \\
\hline Jumlah lantai & 20 -30 lantai & 28 lantai & $\begin{array}{c}\mathrm{KLB} / \mathrm{KDB}= \\
95.200 \mathrm{~m}^{2} / 3.400 \mathrm{~m}^{2}=28 \text { lantai }\end{array}$ \\
\hline $\mathrm{KB}$ & Max. 151,5 m & $98 \mathrm{~m}$ & $\begin{array}{l}\text { Asumsi } 1 \text { lantai 3,5m = } \\
28 \text { lantai x 3,5 m = 98 m }\end{array}$ \\
\hline $\mathrm{KDH}$ & Min 20\% & $30 \%$ & $\begin{array}{c}\text { Luas lahan } \times \mathrm{KDH}= \\
8.500 \mathrm{~m}^{2} \times 30 \%=2.550 \mathrm{~m}^{2}\end{array}$ \\
\hline
\end{tabular}

Sumber: Olahan Penulis, 2020

Aspek teknis yang dilihat adalah bedasarkan analalisis lokasi yang dilakukan terhadap aksesibilias, proximity, penggunaan lahan sekitar, fasilitas, bencana, rencana kota dan tren pengembangan kawasan yang memberikan potensi serta kendala dari lahan pengembangan. Berikut ini adalah potensi dan kendala yang ada.

Tabel 4. Potensi dan Kendala Analisis Lokasi

\begin{tabular}{ll}
\hline \multicolumn{1}{c}{ Potensi } & \multicolumn{1}{c}{ Kendala } \\
\hline Memiliki aksesibilitas yang cukup baik karena & Pusat kegiatan (proximity) berada pada radius \\
disekitar lahan terdapat jalan kolektor, jalan & $10 \mathrm{~km}$ untuk kota Bekasi \\
arteri dan jalan tol serta Stasiun LRT & dan radius 20 km untuk kota Jakarta \\
\hline
\end{tabular}




\section{Potensi}

Tren pengembangan apartemen yang sedang berlansung ke arah stasiun LRT, juga searah dengan lahan.

Rencana pembangunan LRT Jabodebek, Tol Becakayu dam pengembangan Pondokgede sebagai SWK

Penggunaan lahan sekitar lahan yang mayoritas sudah dikembangkan, terutama sebagai kawasan hunian dan campuran

\section{Kendala}

Lokasi tepat dibelakang lahan merupakan lokasi rawan banjir, meskipun dipisahkan oleh aliran anak sungai

Future supply apartemen yang cukup banyak sehingga meningkatkan kompetisi

Hanya terdapat 1 transportasi umum yang melewati lahan

Fasilitas yang tersedia disekitar lahan sudah cukup

beragam

Sumber: Olahan Penulis, 2020

Bedasarkan potensi dan kendala yang ada maka dilakukan analisa, yaitu dengan memiliki aksesibilitas yang baik dan fasilitas sekitar yang cukup banyak untuk menunjang para penghuni apartemen dan dapat menjadi salah satu daya tarik bagi calon pembeli apartemen. Pembangunan Jalur LRT Jabodebek yang mendorong tren pengembangan apartemen disekitar lahan pengembangan, dimana terdapat 2 stasiun LRT yang berjarak 1,5 km dan $3 \mathrm{~km}$ dari lahan pengembangan. Dengan hadirnya LRT maka akan memberikan kemudahan aksesiblitas dengan titik proximity yang terdapat dibeberapa wilayah kota Jakarta. Seiring rencana dikembangkannya kawasan Pondokgede sebagai SWK maka akan dibangun pusat - pusat kegiatan sehingga akan terdapat pusat kegiatan yang lebih dekat dengan lahan pengembangan. Karena lokasi lahan berdekatan dengan lahan banjir dan terdapat aliran sungai dibagian belakang lahan, maka perencanaan pegembangan harus memikirkan hal tersebut.

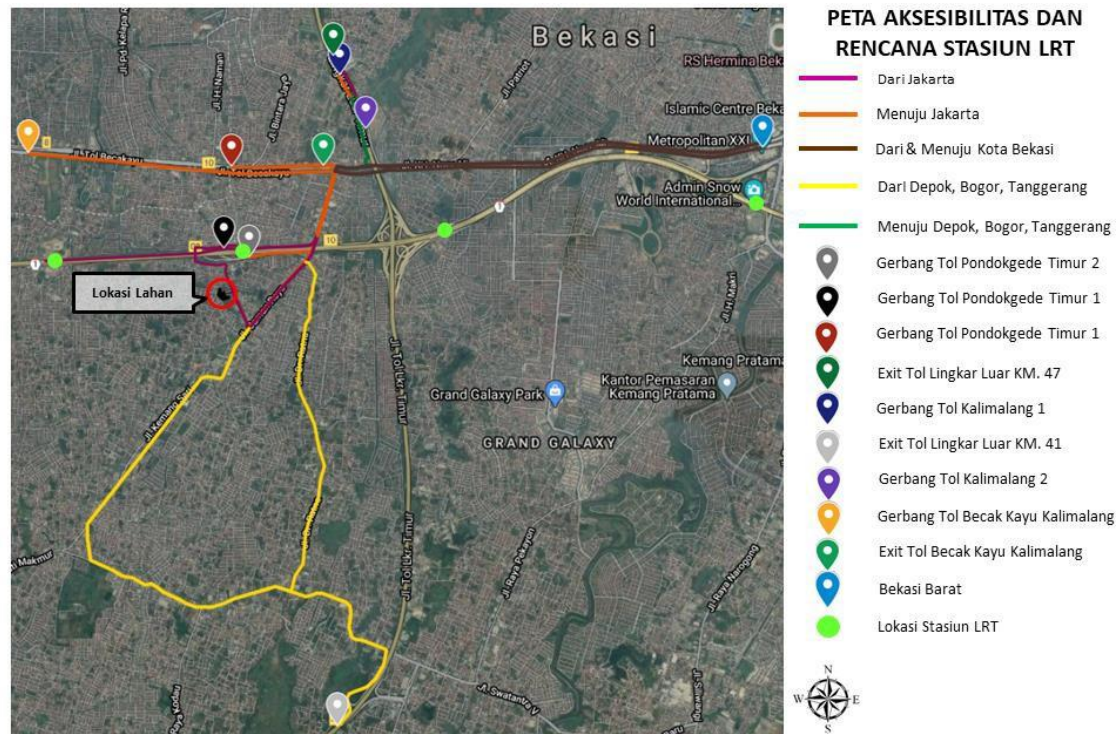

Gambar 3. Peta Aksesibilitas dan Rencana Stasiun LRT Sumber: Olahan Penulis, 2020

Aspek teknis selanjutnya adalah analisis tapak yang dilakukan terhadap kondisi bentuk fisik dari lahan, batas - batas dan dimensi lahan, pencapaian ke tapak, karakteristik sekitar tapak dan nilai lahan. Berikut adalah potensi kendala yang ditemukan: 
Tabel 5. Potensi dan Kendala Analisis Tapak

\begin{tabular}{|c|c|}
\hline Potensi & Kendala \\
\hline $\begin{array}{l}\text { - Memiliki kontur yang landai dan merupakan tanah } \\
\text { siap pakai sehingga tidak mengeluarkan biaya } \\
\text { untuk mengurug atau lain lain }\end{array}$ & $\begin{array}{l}\text { - Bentuk tapak yang tidak beraturan, } \\
\text { serta terdapat sudut - sudut yang tidak } \\
\text { bisa dibangun }\end{array}$ \\
\hline $\begin{array}{l}\text { - Berbatasan dengan tanah kosong di sisi Selatan } \\
\text { yang dapat dijadikan opsi untuk melakukan } \\
\text { ekspansi }\end{array}$ & - Luas tapak yang relatif kecil $(8.500 \mathrm{~m} 2)$ \\
\hline $\begin{array}{l}\text { - Pencapaian ke tapak dapat dilakukan dari } \\
\text { berbagai jalan untuk menuju Jl. Jatibening Raya }\end{array}$ & $\begin{array}{l}\text { - Sirkulasi masuk dan keluar hanya dapat } \\
\text { dilakukan melalui } 1 \text { titik (1 muka) }\end{array}$ \\
\hline $\begin{array}{l}\text { - Tapak memiliki jarak } 80 \mathrm{~m} \text { dengan Jl. Jatibening } \\
\text { yang dapat dijadikan jalan masuk dan jika terjadi } \\
\text { pelebaran jalan tapak tidak terdampak }\end{array}$ & $\begin{array}{l}\text { - Nilai lahan yang sudah termasuk tinggi ( } \\
\text { Rp. } 5.676 .000,-/ \mathrm{m} 2 \text { bedasarkan NJOP) }\end{array}$ \\
\hline $\begin{array}{l}\text { - Karakteristik sekitar lahan sekitar yang } \\
\text { mendukung }\end{array}$ & \\
\hline $\begin{array}{l}\text { - Terletak pada jalan kolektor sekunder dengan } \\
\text { jarak menuju pintu dan masuk tol dalam radius 1- } \\
3 \mathrm{~km}\end{array}$ & \\
\hline $\begin{array}{l}\text { - Legalitas yang mendukung untuk dikembangkan } \\
\text { sebagai komplek apartemen }\end{array}$ & \\
\hline - Terletak di zona hunian kepadatan tinggi & \\
\hline
\end{tabular}

Sumber: Olahan Penulis, 2020

Lahan pengembangan berada pada kawasan yang memiliki karakteristik sebagai hunian, dan berada di jalan kolektor sehingga disekitar tapak juga terdapat area komersial dan campuran yang dapat mendukung bagi sebuah komplek apartemen. Kondisi dari tapak adalah lahan siap pakai dan dikembangkan sehingga dapat menghemat biaya pengeluaran pembangunan, namun dikarenakan tapak memiliki bentuk yang tidak beraturan dan ada sudut yang tidak dapat dikembangkan, maka perencanaan harus memiliki strategi pemanfaatan lahan yang baik. Dengan nilai lahan yang tergolong tinggi (Rp. 5.600.000,-) dapat menjadi bahan pertimbangan dalam menentukan harga jual dan dalam melakukan perbandingan harga dengan kompetitor.
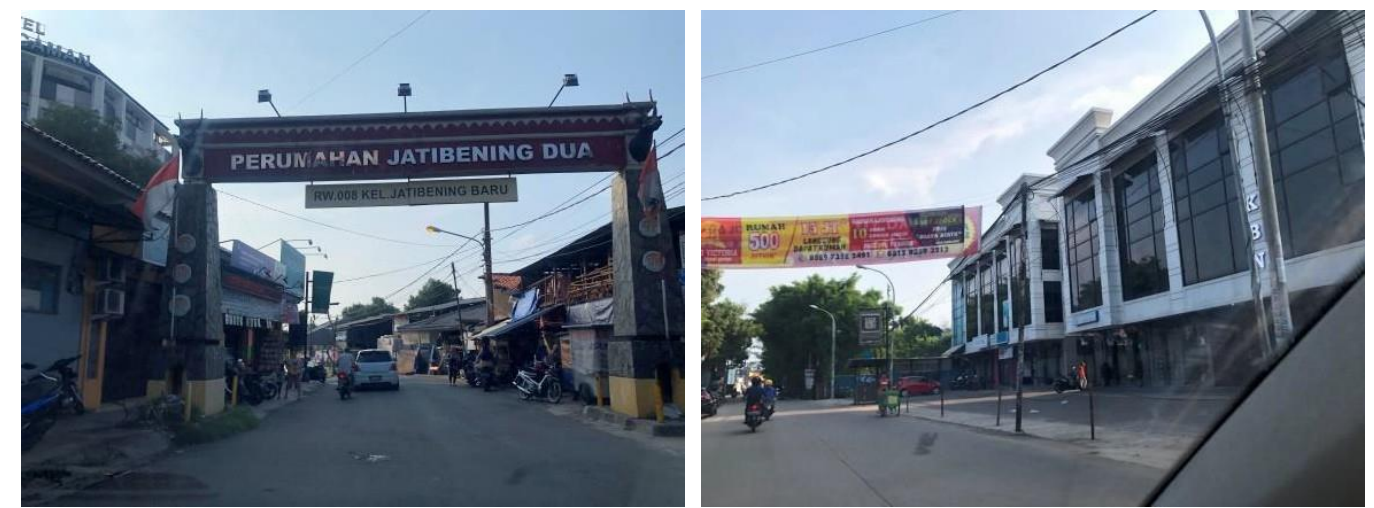

Gambar 4. Karakteristik Sekitar Lahan

Sumber: Dokumentasi Penulis, 2019

Pada analisis Pasar Makro dengan analisis kepada Indikator Makro Ekonomi seperti Inflasi, Kurs, PDB, Suku Bunga, Penanaman Modal Dalam Negeri dan Asing serta IHSG dengan data yang didapatkan selama 5 tahun terakhir, yaitu dari tahun 2014 - triwulan 2 2020), didapatkan bahwa situasi ekonomi di Indonesia secara keseluruhan hingga triwulan 22020 berada pada kondisi yang baik, namun pada saat ini dengan mewabahnya pandemi COVID-19 di Indonesia pada awal Maret 2020 membuat kondisi ekonomi tidak berada dalam kondisi yang baik sehingga Bank 
Indonesia pun merevisi beberapa nilai indikator makro ekonomi. Keadaan ekonomi ini dialami hampir diseluruh dunia yang terdampak pandemi COVID-19. Namun seiring penanganan yang dilakukan oleh setiap negara, maka diprediksi bahwa keadaan ekonomi di Indonesia akan kembali normal pada tahun 2021. Sehingga lahan pengembangan akan direncanakan dikembangkan pada triwulan 12021 dengan tujuan menyesuaikan kondisi ekonomi di Indonesia.

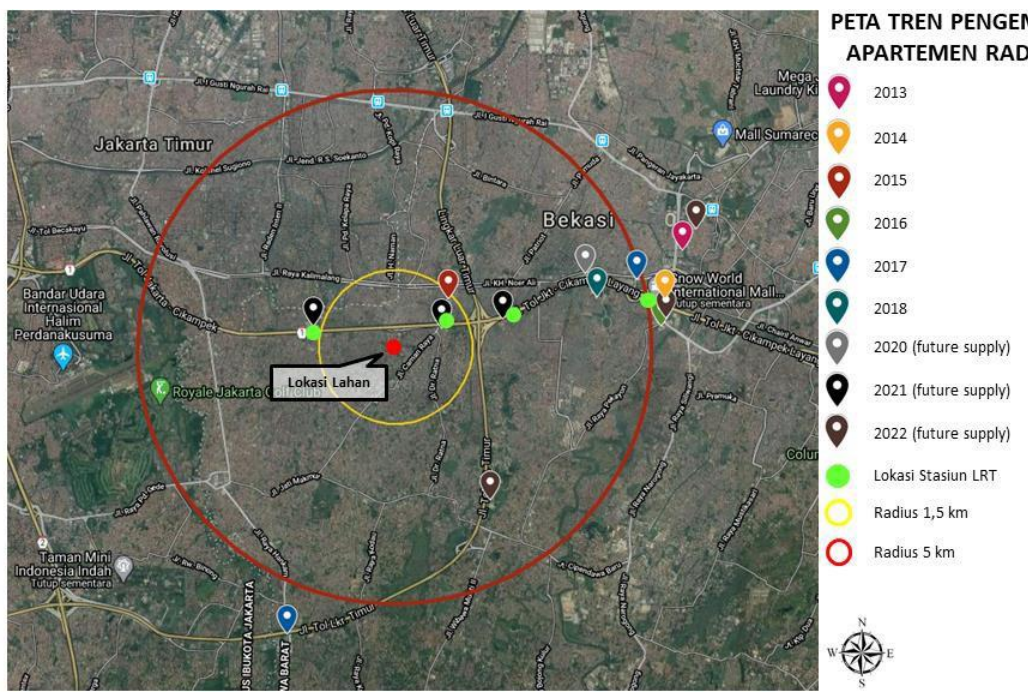

Gambar 5. Peta Tren Pengembangan Apartemen di Radius 5km Sumber: Olahan Penulis, 2020

Tren perkembangan apartemen yang dilihat adalah pada radius $5 \mathrm{~km}$ dari objek studi, pada radius $5 \mathrm{~km}$ ini akan mencakup wilayah Jatibening dan Bekasi Barat yang memiliki kesamaan yaitu dilewati oleh jalur LRT. Tren perkembangan apartemen dimulai pada tahun 2013 dan terdapat 7 apartemen yang sedang konstruksi (future supply) yang akan beroperasi antara tahun $2020-2022$.

Tabel 6. Tren Pengembangan Apartemen dalam Radius $5 \mathrm{~km}$

\begin{tabular}{cllccc}
\hline No. & \multicolumn{1}{c}{ Nama Apartemen } & Jenis & Kelas & $\begin{array}{c}\text { Takeup Rate / } \\
\text { Occupancy }\end{array}$ & Status \\
\hline 1 & Centerpoint Apartmenen & Strata & Middle Low & $75 \%$ & Operation \\
\hline 2 & Apartemen Mutiara Bekasi & Strata & Middle Low & $70 \%$ & Operation \\
\hline 3 & Grand Icon Caman & Strata & Middle & $90 \%$ & Operation \\
\hline 4 & Kemang View Apartemen & Strata & Middle & $80 \%$ & Operation \\
\hline 5 & Grand Dhika Jatiwarna & Strata & Middle & $70 \%$ & Operation \\
\hline 6 & M Gold Tower & Strata & Middle Up & $60 \%$ & Operation \\
\hline 7 & Grand Kamala Lagoon & Strata & Middle Up & $85 \%$ & Operation \\
\hline 8 & Metro Galaxy Park Apartemen & Strata & Middle Up & $55 \%$ & Construction \\
\hline 9 & Taman Sari Urban Sky & Strata & Middle & $65 \%$ & Construction \\
\hline 10 & LRT City Jati Cempaka & Strata & Middle & $70 \%$ & Construction \\
\hline 11 & Apartemen Conexio & Strata & Middle & $80 \%$ & Construction \\
\hline 12 & The MAJ Residences & Strata & Middle & $70 \%$ & Construction \\
\hline 13 & Thamrin District Apartemen & Strata & Middle Low & $55 \%$ & Construction \\
\hline 14 & Kota Swarnabumi Cikunir & Strata & Middle Low & $45 \%$ & (Pending) \\
\hline
\end{tabular}

Sumber: Olahan penulis, 2020

Dari seluruh supply apartemen yang ada baik eksisting atau future supply, seluruhnya adalah berjenis strata title (apartemen jual) dengan kelas yang paling mendominasi adalah Middle. Analisis benchmarking dilakukan terhadap apartemen kompetitor yang paling sejenis yang masih dalam masa pembangunan, yaitu Apartemen Conexio, LRT City Jati Cempaka dan Taman 
Sari Urbansky untuk dijadikan salah satu acuan dalam penentuan komposisi produk. Ketiga apartemen tersebut memiliki 3 jenis tipe unit yaitu, Studio, 1BR dan 2BR dengan jumlah unit total perlantai tipikal antara 32-68 unit dengan komposisi unit rata - rata untuk tipe studio adalah 70\%, 1 BR 17\% dan 2BR 13\% dari total jumlah unit.

Bedasarkan keadaan dari pasar kompetitor tersebut, maka apartemen yang akan dikembangkan akan memiliki 3 tipe yaitu, Studio, 1BR dan 2 BR dengan kelas Middle dengan jenis strata title. Targetting dari apartemen pengembangan adalah penduduk usia produktif ( $20-64$ tahun) yang diharapkan adalah para commuter yang akan menggunakan transportasi massal LRT yang sedang dibangun dan apartemen pengembangan memposisikan diri sebagai market follower yang artinya pengembangan dandidasarkan kepada kondisi pasar yang ada. Berikut ini adalah kebutuhan ruang dan komposisi produk yang direncanakan pada apartemen pengembangan:

Tabel 7. Rencana Kebutuhan Ruang Produk Bangunan

\begin{tabular}{cccc}
\hline Jenis Produk & Jumlah Lantai & Luas (GFA) & Luas (NLA unit dijual) \\
\hline Apartemen & 27 lantai & $91.800 \mathrm{~m} 2$ & $41.310 \mathrm{~m} 2$ \\
\hline Retail & 1 lantai & $3.400 \mathrm{~m} 2$ & $2.550 \mathrm{~m} 2$ \\
\hline
\end{tabular}

Sumber: Olahan penulis, 2020

Produk yang akan dikembangkan pada lahan adalah apartemen dengan luas NLA unit yang dapat dijual adalah $41.310 \mathrm{~m}^{2}$ dan retail dengan luas unit NLA adalah $2.550 \mathrm{~m}^{2}$. Posisi dari retail yang akan dikembangkan adalah sebagai supporting facilities dari apartemen yang bertujuan untuk memenuhi kebutuhan sehari - hari para penghuni apartemen nantinya, sehingga retail dibedakan dalam 2 jenis yaitu, 60\% untuk Area Basah (Food and Beverages) dan $40 \%$ untuk Area Non Basah seperti area untuk minimarket, laundry, kantor pengiriman barang dan lain lain yang dihitung dari NLA retail dengan harga per $\mathrm{m}^{2} \mathrm{Rp}$. 23.577.090,- . Sedangkan untuk apartemen akan dibedakan kedalam 3 tipe unit yaitu, Studio, 1BR dan 2 BR dengan harga per $\mathrm{m}^{2} \mathrm{Rp}$. 21.433.718,- . Berikut ini adalah tipe unit dari apartemen yang dikembangkan:

Tabel 8. Rencana Tipe dan Luasan Unit Apartemen

\begin{tabular}{cccc}
\hline Tipe Unit & Luas Unit & Dimensi & Harga Jual/unit \\
\hline Studio & $28 \mathrm{~m}^{2}$ & $7 \times 4$ & Rp. 600.144 .100 \\
\hline $1 \mathrm{BR}$ & $42 \mathrm{~m}^{2}$ & $7 \times 6$ & Rp. 900.216 .150 \\
\hline $2 \mathrm{BR}$ & $56 \mathrm{~m}^{2}$ & $7 \times 8$ & Rp. 1.200 .288 .199 \\
\hline
\end{tabular}

Sumber: Olahan Penulis, 2020

Selanjutnya adalah dikembangkan kedalam 3 alternatif produk dimana setiap alternatif memiliki perbedaan persentase komposisi tipe unit yang dilakukan perhitungan bedasarkan luas NLA unit apartemen. Berikut adalah alternatif komposisi unit apartemen pengembangan:

Tabel 9. Alternatif Komposisi Unit

\begin{tabular}{lcccccc}
\hline & $\begin{array}{c}\text { Persentase } \\
\text { Tipe Studio }\end{array}$ & $\begin{array}{c}\text { Jumlah Unit } \\
\text { Tipe Studio }\end{array}$ & $\begin{array}{c}\text { Persentase } \\
\text { Tipe 1 BR }\end{array}$ & $\begin{array}{c}\text { Jumlah Unit } \\
\text { Tipe 1BR }\end{array}$ & $\begin{array}{c}\text { Persentase } \\
\text { Tipe 2BR }\end{array}$ & $\begin{array}{c}\text { Jumlah Unit } \\
\text { Tipe 2BR }\end{array}$ \\
\hline Alternatif 1 & $70 \%$ & 1.033 & $60 \%$ & 885 & $55 \%$ & 811 \\
\hline Alternatif 2 & $17 \%$ & 167 & $30 \%$ & 295 & $33 \%$ & 325 \\
\hline Alternatif 3 & $13 \%$ & 96 & $10 \%$ & 74 & $12 \%$ & 3 \\
\hline Total & $100 \%$ & 1.296 & $100 \%$ & 1.254 & $100 \%$ & 1.225 \\
\hline
\end{tabular}

Sumber : Olahan Penulis, 2020

Terdapat 3 alternatif komposisi produk yang direncanakan. Alternatif 1 didasarkan pada rata rata komposisi dari kompetitor yang di benchmarking, sedangkan alternatif 2 dan 3 merupakan penyesuaian dari kondisi pasar yang didasarkan oleh Peraturan Pemerintah untuk menetapkan 
perbandingan antara Tipe Atas : Tipe Menengah : Tipe Terendah. Pada alternatif 2 perbandingan yang digunakan adalah $6: 3: 1$ sedangkan pada alternatif 3 perbandingan yang digunakan adalah $5: 3: 1$. Melalui ketiga alternatif komposisi produk ini dilakukan analisis investasi untuk melihat alternatif yang dapat memberikan tingkat pengembalian investasi terbaik.

Pembiayaan pembangunan apartemen ini direncanakan menggunakan $40 \%$ modal dari developer bedasarkan perkiraan biaya pembangunan (project investment), sedangkan sisa kekurangan pembangunan akan dipenuhi menggunakan pendapatan penjualan unit pertahun dan dana pinjaman bank (bank loan) dengan bunga pinjaman adalah 10\%/ tahun dan direncanakan akan diambil selama 2 tahun. Pada proses penjualan unit apartemen dan retail, developer bekerja sama dengan bank HSBC untuk menerapkan skema pembayaran via cicilan KPA. Skema pembayaran dari KPA ini adalah maksimal 90\% dari total harga unit yang dapat dijadikan cicilan KPA, sedangkan sisanya adalah DP yang wajib dibayarkan kepada developer dan developer akan menerima pembiayaan KPA dari bank setelah calon pembeli melunasi DP dan melakukan proses untuk cicilan KPA dan disetujui.

Maka pada penjualan unit apartemen yang direncanakan, diberikan 4 kategori skema pembayaran yaitu Hard Cash, KPA dengan cicilan DP 3X, KPA dengan cicilan DP 12X dan KPA dengan cicilan DP 24X. Cicilan DP ini dilakukan langsung kepada developer namun dikenakan perbedaan harga untuk setiap skema pembayaran. Untuk skema pembayaran Hard Cash diberikan diskon 3\% dari total harga unit, untuk KPA DP Cicilan 3x diberikan harga unit normal, untuk KPA DP Cicilan 12x diberikan penambahan harga $5 \%$ dari harga unit normal dan untuk KPA DP Cicilan $24 x$ diberikan penambahan harga $10 \%$ dari harga unit normal. DP yang wajib dibayarkan adalah $20 \%$ dari total harga unit.

Pada penjualan unit retail yang direncanakan diberikan 3 kategori skema pembayaran yaitu Hard Cash, KPA dengan cicilan DP 12X, KPA dengan cicilan DP 24X. Untuk ketentuan skema cicilan sama seperti penjualan unit apartemen dimana terdapat perbedaan harga bedasarkan skema cicilan yang dipilih. Untuk skema pembayaran Hard Cash diberikan diskon 3\% dari total harga per $\mathrm{m}^{2}$, untuk KPA DP Cicilan 12x diberikan penambahan harga $3 \%$ dari harga per $\mathrm{m}^{2}$ normal dan untuk KPA DP Cicilan 24x diberikan penambahan harga 8\% dari harga per $m$ normal.

Skema penjualan dibedakan kedalam 3 skema yaitu pesimis, moderate dan optimis. Setiap skema penjualan dibedakan bedasarkan asumsi tingkat takeup rate penjualan. Dasar dari persentase takeup rate yang diasumsikan adalah bedassarkan kompetitor yang memiliki takeup rate rata - rata $25 \%$ - 40\% per tahun. Sehingga dengan asumsi 3 tahun penjualan untuk skema penjualan pesimis takeup rate adalah sebesar $80 \%$, moderate $90 \%$ dan optimis $95 \%$. Sedangkan untuk retail dengan asumsi penjualan 4 tahun memiliki tingkat takeup rate yang sama dengan apartemen, dikarenakan sebagai supproting facilites dari apartemen penjualan retail diasumsikan baru akan mencapai puncaknya ketika apartemen sudah beroperasi atau ketika apartemen mencapai tingkat takeup rate tertinggi sehingga terdapat perbedaan waktu penjualan 1 tahun. Sehingga berikut ini adalah perhitungan analisis investasi yang dilakukan pada setiap alternatif komposisi dengan menggunakan perhitungan cashflow:

Tabel 10. Cashflow Alternatif Komposisi 1

\begin{tabular}{cccl}
\hline $\begin{array}{c}\text { Skema } \\
\text { Penjualan }\end{array}$ & \multicolumn{1}{c}{ Total Cash In } & \multicolumn{1}{c}{ Total Cash Out } & \multicolumn{1}{c}{ NPV, IRR, PI dan PP } \\
\hline & & & NPV $=-$ Rp. 63.374.180.597 \\
Pesimis & Rp. 1.090.049.815.186 & Rp. 1.043.669.536.992 & $\begin{array}{l}\text { IRR 4,31\% } \\
\text { PI 1,04 } \\
\end{array}$ \\
& & & PP 4,79 \\
\hline
\end{tabular}




\begin{tabular}{cccl}
\hline $\begin{array}{c}\text { Skema } \\
\text { Penjualan }\end{array}$ & \multicolumn{1}{c}{ Total Cash In } & \multicolumn{1}{c}{ Total Cash Out } & \multicolumn{1}{c}{ NPV, IRR, PI dan PP } \\
& & & NPV $=$ Rp. 17.494.721.537 \\
Moderate & Rp. 1.173.192.328.230 & Rp. 1.018.692.056.208 & $\begin{array}{l}\text { IRR 14,1\% } \\
\text { PI 1,15 } \\
\end{array}$ \\
& & & PP 4,31 \\
\hline & & & NPV $=$ Rp. 57.101.461.833 \\
& & & IRR 19\% \\
Optimis & Rp. 1.212.396.799.510 & Rp. 1.004.463.944.075 & PI 1,2 \\
& & & PP 4,06 \\
\hline
\end{tabular}

Sumber: Olahan Penulis, 2020

Tabel 11. Cashflow Alternatif Komposisi 2

\begin{tabular}{|c|c|c|c|}
\hline $\begin{array}{c}\text { Skema } \\
\text { Penjualan }\end{array}$ & Total Cash In & Total Cash Out & NPV, IRR, PI dan PP \\
\hline Pesimis & Rp. 1.086.930.015.830 & Rp. 1.041.653.957.543 & $\begin{array}{l}\text { NPV }=- \text { Rp. } 63.960 .016 .197 \\
\text { IRR } 4,2 \% \\
\text { PI 1,0 } \\
\text { PP 4,8 }\end{array}$ \\
\hline Moderate & Rp. 1.175.771.781.249 & Rp. 1.016.221.819.415 & $\begin{array}{l}\text { NPV = Rp. } 21.613 \cdot 353.470 \\
\text { IRR } 15 \% \\
\text { PI } 1,16 \\
\text { PP } 4,28\end{array}$ \\
\hline Optimis & Rp. 1.214.915.942.317 & Rp. 998.246.404.326 & $\begin{array}{l}\text { NPV = Rp. 63.859.945.334 } \\
\text { IRR } 20 \% \\
\text { PI 1,22 } \\
\text { PP 4,01 }\end{array}$ \\
\hline
\end{tabular}

Sumber: Olahan Penulis, 2020

Tabel 12. Cashflow Alternatif Komposisi 3

\begin{tabular}{|c|c|c|c|}
\hline $\begin{array}{c}\text { Skema } \\
\text { Penjualan }\end{array}$ & Total Cash In & Total Cash Out & NPV, IRR, PI dan PP \\
\hline Pesimis & Rp. 1.090.340.107.790 & Rp. 1.042.683.292.371 & $\begin{array}{l}\text { NPV }=- \text { Rp. } 62.413 .288 .582 \\
\text { IRR } 4,4 \% \\
\text { PI 1,04 } \\
\text { PP } 4,79\end{array}$ \\
\hline Moderate & Rp. 1.178.652.563.424 & Rp. 1.019.404.916.674 & $\begin{array}{l}\text { NPV = Rp. } 20.788 .374 .859 \\
\text { IRR } 14,5 \% \\
\text { PI } 1,16 \\
\text { PP } 4,29\end{array}$ \\
\hline Optimis & Rp. 1.219.964.892.777 & Rp. 1.002.440.045.898 & $\begin{array}{l}\text { NPV }=\text { Rp. } 64.014 .096 .890 \\
\text { IRR } 20 \% \\
\text { PI 1,22 } \\
\text { PP 4,02 }\end{array}$ \\
\hline
\end{tabular}

Sumber : Olahan Penulis, 2020

Cashflow yang dihitung adalah selama 6 tahun yaitu dari tahun 2021 saat dimulainya penjualan hingga tahun 2026 dimana penerimaan terakhir didapatkan dari penjualan retail dengan skema KPA cicilan 24x. Total Cash In yang didapatkan adalah hasil penjualan unit apartemen dan retail serta dana pinjaman bank (bank loan) yang dilakukan pada tahun ke 2 (2022). Sedangkan untuk cashout didapatkan dari rencana biaya pengembangan (project investment) yang ditambah dengan biaya promosi, marketing eksternal, marketing internal serta cicilan bank loan yang dibayarkan pada tahun ke 3 (2023) dan tahun ke 4 (2024). 


\section{KESIMPULAN DAN SARAN \\ Kesimpulan}

Lahan pengembangan disimpulkan layak dikembangkan sebagai apartemen karena bedasarkan peraturan legalitas telah memenuhi persyaratan teknis yang ada dan peraturan KKOP Bandara Halim Perdana Kusuma, serta dari sisi lokasi dan tapak dengan ditemukannya potensi serta masalah yang ada, melalui strategi yang baik akan dapat meminimalkan masalah yang juga dapat dikombinasikan dengan potensi yang ada. Dengan teridentifikasinya kondisi pasar yang ada, maka dapat disimpulkan bahwa pengembangan apartemen yang memungkinkan adalah dengan kelas Middle, berjenis strata title dengan maksimal unit 1.313 unit dan perkiraan harga per $\mathrm{m}^{2}$ adalah Rp. 21.433.718,-. Selain itu dapat dilihat juga komposisi produk yang dapat dikembangkan adalah $55-70 \%$ untuk tipe studio, 17\% - 33\% untuk tipe 1 BR dan untuk tipe 2 BR $10 \%$ - 13\% dengan pengembalian investasi terbaik adalah yang memberikan NPV Rp. 63.859.954.334, IRR 20\%, PI 1,22 dan waktu payback periode 4, 01 yang berarti dalam waktu 4 tahun.

\section{Saran}

Dengan kondisi makro ekonomi pada tahun 2020 yang terkena dampak dari pandemi COVID-19 maka direkomendasikan bahwa pengembangan dilakukan pada Q1 2021 seperti yang telah diperhitungkan dalam analisis investasi dengan tujuan untuk menunggu kondisi ekonomi kembali normal. Dari analisis investasi juga direkomendasikan bahwa alternatif komposisi produk yang dapat memberikan pengembalian investasi terbaik adalah Alternatif 2 , karena memberikan nilai NPV, IRR dan PI serta payback yang paling baik jika dibandingkan alternatif lainnya dari skema penjualan yang ada.

\section{REFERENSI}

Braid, F. M., \& Kyle, R. C. (1991). Property Management, Fourth Edition. Real Estate Education Company.

Halim, A. (2003). Analisis Investasi Edisi Pertama. Jakarta: Salemba Empat.

Hamidah, C. (2016). Investasi Properti Sebagai Pilihan Keluarga Tenaga Kerja Indonesia (TKI) di Kecamatan Babadan Kabupaten Ponorogo, 4.

Harris, C. M. (1975). Dictionary of Architecture and Construction. Mc Graw Hill Book Comp.

Hazen, G. B. (2003). An Extension of the Internal Rate of Return to Stochastic Cash Flows.

Huxham, A. (2010). Property Development: Feasibility and impact parameters in the Vaal Triangle. 13 - 33.

Ikatan Akuntan Indonesia. (2005). Pernyataan Standar Akuntansi Keuangan (PSAK) No. 2. Jakarta: Salemba Empat. 